\title{
Implementation of 4PS Conditional Cash Transfer and Students' School Attendance in Don Vicente Romualdez National High School
}

\author{
Christilyn Juarez Arcayna, Jonelyn Juarez Arcayna, Resty Juarez Arcayna \\ Department of Education, Commission On Higher Education, Philippines
}

\begin{abstract}
The conditional cash transfer program of 4Ps is a social program that entails monetary assistance that contributes to the education of beneficiaries. This study aimed at finding out if the implementation of the 4Ps conditional cash transfer program in terms of health and education is related to the students' school attendance. The respondents of this study were 4Ps recipient students of Don Vicente Romualdez National High School. A descriptive - correlational study was employed utilizing a representative sample of all 4Ps beneficiaries from Grade 7 to Grade 12. Findings revealed that the implementation of 4Ps Conditional Cash Transfer programs in terms of health and education grants is high. Findings also revealed that students' percentage of school attendance met the standard requirements of 4Ps and DepEd policy, which is $80 \%$ of the total number of days. It is then recommended that the Philippine Government continue the implementation of 4Ps and design additional programs for beneficiaries who graduated through the CCT.
\end{abstract}

\section{THE PROBLEM AND RELATED LITERATURE}

\section{Introduction}

Chool attendance has been a major problem especially for $\boldsymbol{N}$ the student who belongs to an unfortunate family. Many less fortunate families cannot provide education for their children. Some parents can only afford to provide their families with one meal a day, and they cannot even send their children to school.

Sometimes parents encourage their children to work and earn for their living so that they can have something to eat and parents cannot be blamed because sometimes it is better to have something for a meal than to have something to feed in mind (Jacobsen, Meeder, \& Voskuil, 2016)

In many developing countries, the governments lack either the financial resources or the political will to meet their citizens' educational needs. In response, parents in some lowincome countries have organized and paid for their children's education themselves. As stipulated by Hillman (2013), school fees and other payments are indeed a heavy burden for some parents to bear.

The right to education plays a key role in achieving Education For All (EFA) and the Millennium Development Goals (MDGs), namely: eradicate extreme poverty and hunger, achieve universal primary education, reduce child mortality, improve maternal health and promote gender equality by localizing poverty reduction efforts through Pantawid Pamilyang Pilipino Program and is central in the context of the post-2015 agenda. As underlined by the United Nation (UN) Special Rapporteur, all development goals have educational dimensions, and the right to education provides indispensable leverage for development, and children are mandated to a favorable, quality education (UNICEF \& Regional Office for Central \& Eastern Europe, 2007)

In the Philippines, the Department of Education is determined to increase the population of the students and to decrease the number of drop-outs of students per year by partnering with the Department of Social Welfare and Development (DSWD). Estabillo (2011) reports that it helped to solve the problem through the implementation of the Pantawid Pamilyang Pilipino Program or commonly known as 4Ps. Thus, helping the country meet the Millennium Development Goals (MDGs).

This implementation, however, was controversial. As Montilla, Delavin, \& Villanueva Jr. (2015) claim, some issues emerged towards the proper use of cash grants. This is so because other parents or guardians spend the money on gambling and other expenditures instead of complying with the conditions.

In Laak, Compostela Valley Province, particularly in Don Vicente Romualdez National High School, it was observed that in the first quarter of the school year, there was a big turnout of enrollees. However, in the second to the last part of the school year, the number of students gradually decreased. Thus, contributing to the percentage of dropouts every year. Also, it has been noticed that the learners' attendance is affected by their financial problems. The guidance advocate of the said school has validated the claim. In the context of the said concern, this study was conceived to determine whether the implementation of the 4Ps Conditional Cash Transfer Program has a significant relationship to the students' attendance in Don Vicente Romualdez National High School.

\section{Review of Related Literature}

This section contains a review of research literature about the variables and indicators considered in this study. 
This includes the implementation of the 4Ps cash grants and school attendance of 4PS recipients in Don Vicente Romualdez National High School. A thorough examination of journals, books, unpublished theses, articles from the internet was conducted to support the findings of the research problem presented for its relevance.

South Africa introduced its version of the child support grant. The widespread success of these programs has inspired other countries in Africa and Asia.

\section{Conditional Cash Transfer Grants}

The 4Ps program, according to Carbayas (2012), is said to help in fulfilling the country's commitments in meeting the Millennium Development Goals (MDG). He goes on to say that a study by the United Nations (UN) projected that by the year 2000, the overall probability of attaining the targets remain high. However, it depends largely on the "interaction" of several factors such as leveling-up of current efforts on all target areas, efficient use of allocated and limited resources, additional resources, strong advocacy, and the capability to implement the MDGs at the local level.

Bailey \& Hedlund (2012) contend that cash transfer programming is now widely accepted. This has been found as a way to meet a variety of needs in humanitarian and transitional settings.

Appropriate cash enables students to buy school materials and projects according to their priorities and attended school regularly. Although the literature on cash transfers has grown exponentially over the last few years, their use in humanitarian interventions, the relationship between cash transfer interventions in crisis contexts and attendance has received little attention. This is surprising given that many cash transfers have educational objectives, such as improving access to an adequate quantity and quality of education and attendance of the recipients (Estabillo, 2011).

In the international context, the conditional cash transfer (CCT) program become prevalent both in developing and developed nations. Accordingly, several studies have determined both the challenges and opportunities of conditional cash transfer especially in its educational performance. Some issues that confront the performance include the attention given to addressing the gender gap (Reyes, Tabuga, Mina, \& Asis, 2013) and on building the human capital of poorest families (health/nutrition and education) given the observation that low schooling, ill health, and high malnutrition are strongly associated with the poverty cycle (DSWD, 2009).

Several evaluations and assessments of CCT have shown positive effects concerning the human capital acquisition by participants in the programs, (Behrman, Sengupta, \& Todd, 2000; Fernald, Gertler, \& Neufeld, 2008). In particular, Garza and Villarreal (2007) reported that CCT appears quite successful in incrementing schooling among the poor (enrollment). The fact that this type of program permits good targeting enables them as an efficient tool for social policy (Lindert, Skoufias, \& Shapiro, 2006). While the "quantity" component of the acquired human capital has been studied to a considerable extent, much less has been said about the "quality" component. The issue is far from trivial if the quality component is not considered the accumulation of human capital may be overestimated (underestimated). Concerning schooling, the latter may have a profound effect on productivity, the acquisition of further human capital, and signaling in the labor markets (Garza \& Huerta, 2014; Lange \& Topel, 2004).

Mo, Zhang, Yi, \& Luo, (2012) have also shown that CCTs can be effective in boosting school enrolment and decreasing school dropout. In Africa for instance, conditional cash transfer grants are limited to households and one major challenge in measuring the program's effect on academic performance is that schools attended by treatment group subjects are likely to undergo compositional change due to increases in enrolment. This, in turn, may alter the relative measurements obtained on relevant variables from the beneficiary and non-beneficiary groups.

Garcia and Hill (2009) have cited Behrman, Sengupta, \& Todd (2005), De Janvry (2006), and Lavinas (2001) respectively that studies in Mexico and Brazil have compared grade retention rates and test scores between CCT beneficiaries and non-beneficiaries. Results show that for those age groups for which there are enrolment effects, the beneficiary group achievement is lower than non-beneficiary group achievement. This may indicate that those re-enrolling or not dropping out because of the CCT program have lower achievement than non-beneficiaries. The difference between the beneficiary and non-beneficiary groups means a simple comparison of grade retention rates or average test scores between groups cannot produce an unbiased effect estimate, even if the beneficiary status is randomly assigned.

Brazil and Mexico were the first countries to implement the concept of a CCT program. The main objective was to provide cash to families who were in extreme poverty in exchange for some education and health care commitments. Since then, many countries, including the Philippines through its 4Ps, have attempted to replicate their examples. The 4Ps as adapted from the CCT Programs in Latin America is a poverty-reduction strategy that provides cash grants to extremely poor households to allow the members of the families to meet certain human development goals (Reyes, Tabuga, Mina \& Asis, 2013).

Low-income parents are often overwhelmed by diminished self-esteem, depression, and a sense of powerlessness, and inability to cope with the feelings that may get passed along to their children in the form of insufficient nurturing, negativity, and a general failure to focus on children's needs (Jensen, 2009). In a study of emotional problems of children of single mothers, Eamon \& Zuehl (2001) found that the stress of poverty increases depression 
rates among mothers, which results in increased use of physical punishment. Children themselves are also susceptible to depression: research shows that poverty is a major predictor of teenage depression children raised in poverty rarely choose to behave differently, but they are faced daily with overwhelming challenges that affluent children never have to confront, and their brains have adapted to suboptimal conditions in ways that undermine good school performance (Denny, 2004).

The mass-based population of the country is struggling to combat the poverty problem in the urban and rural areas. They are the least fortunate people deprived of economic, social, and political well-being and whose plight needs an immediate solution by the government. It is the fundamental obligation of the state to promote the family as the foundation of the nation, strengthen its solidarity to ensure total development. In support of the national policy, the Department of Social Welfare and Development launched the Pantawid Pamilyang Pilipino Program (4Ps), in coordination with the Department of Health and the Department of Education as well as, the Department of Interior and Local Government. This program is a strategy for poverty reduction and as a measure that provides conditional cash transfer to the extremely poor households to allow the members of the families to meet certain human development goals set by the government (Cecchini \& Madariaga, 2011).

The program identified dual objectives, first, Social Assistance, to provide cash assistance to the poor to alleviate their primary needs and last is the Social Development, to break the intergeneration cycle of poverty through investment in human capital (DSWD, 2008).

The Arroyo administration conceived of the Pantawid Pamilyang Pilipino Program as a flagship project to reduce poverty through investment in human capital. According to the DSWD (2005), the household beneficiaries receive as much as $\mathrm{P} 1,400$ for a maximum of three children including the monthly P500 for nutrition and health expenses and P300 per child (maximum of three per household) for the monthly educational expenses. To continue receiving grants, household beneficiaries must comply with certain conditions. These conditions are that parents must ensure that their children attend school at least $85 \%$ of the time and receive vaccinations and health care. Pregnant women must receive pre- and post-natal care and be attended by a skilled health professional during childbirth. They must attend responsible parenthood seminars, mothers' classes, and parent effectiveness seminars.

These services are provided to the beneficiaries, aside from cash transfers. And, as Cecchini \& Madariaga (2011), added: the 4Ps is a social program that entails monetary and non-monetary transfers to the poor or poorest families that have school-age children on the condition that they meet certain terms that are aimed at improving their capacities.
The proclamation of SB No. 3412 also known as Pantawid Pamilyang Pilipino Program (4Ps) has been a big help to the youth, as the primary beneficiaries. The program aims to help not only the youth of Metro Manila but also the youth of the whole country. The government of the Philippines is one of the institutions that guide or motivate to succeed. It prioritizes the rights, focusing on the children and the basic needs of the nation, especially in education.

Velarde and Fernandez (2011) also added that the impact of Conditional Cash Transfer of 4Ps in improving the educational and health outcomes could aid and support beneficiaries in attaining a better and quality living in the future. Like the lessons learned from other CCT programs, 4Ps are also intended to fill gaps in the educational and health outcomes amongst children, aside from providing them with immediate poverty relief. The Pantawid Pamilyang Pilipino Program, like other Conditional Cash Transfers, employed for varied but interrelated purposes today, has proven to have an impact on education, either directly, using the educational and health grants of the program, or indirectly, by uplifting the total human condition of its recipients.

A study in Masbate Province revealed that learners who are beneficiaries of Conditional Cash Transfer Grants(CCT) of the 4Ps had complied with the requirements, projects, and contributions. However, $18 \%$ said they never complied with the requirements in school. Findings also revealed that $3(27 \%)$ teachers encountered difficulties in absenteeism and lack of attention of the identified CCT learners. This entails that most of 4Ps CCT beneficiary students did not abide by the requirements like paying school PTA contributions and students' school attendance. One of the respondents asserted that the budget for the contribution of the project is spent on other expenses, like gambling, and hard liquor (Montilla, 2015). Further, Torre (2016) in his study concludes that 4Ps certainly helped its recipients and the school with 4Ps enrollees.

Health Grants. The National Nutritional Survey (2010) presented that the impact of diet and nutrition on school attendance in developing countries is difficult to assess and can be confounded by socio-economic status, school factors, and other variables. There is growing and convincing evidence for a link between diet and nutrition on school attendance in countries with advanced economies. Research has shown that malnourished children or children who eat unhealthy diets, for example, manifest several behaviors that can interfere with learning and students attendance. Sigfúsdóttir (2007) asserted that children and adolescents whose diets are nutritious and whose participation in physical activity is high tends to perform better on various measures of cognitive performance and students' attendance in school.

Several reports in both the United States and Europe have revealed the negative effect of obesity among children and adolescents. In the most recent review of research articles published between 1994 and 2004, Taras and Potts-Datema (2005) identified ten studies from around the world that 
examined the relationship between obesity and outcomes and school performance, including measures of student academic achievement, cognitive ability, or school attendance. The conclusion was that while the body of published work was small and methodologically limited, the preponderance of evidence from these studies showed that overweight and obese children and adolescents generally do not perform as well, or attend school as much, as their healthy counterparts. Such findings are difficult to interpret; however, because school performance is confounded by school attendance and other factors, such as mental health, low self-esteem, or depression. In addition to the findings on diet and academic achievement, a strong connection has been established between physical activity and positive academic outcomes.

According to Jyoti, Frongillo, and Jones (2005), food insecurity has consequences for attending class, social skills, and weight in children. Food insecurity has been associated with diverse developmental consequences for U.S. children primarily from cross-sectional studies. These cross-sectional studies suggest possible associations between food insecurity and overweight in children in the student's attendance.

As stipulated by Glewwe (2012), malnourished children perform more poorly in school. This is even after correcting for the effects of unobserved heterogeneity both across and within households.

The possibility of a strong connection between nutrition and learning is of growing importance. As a result, the relationship between nutrition, health, and learning is undeniably strong and has an impact on a child's development (Chulack, 2016). Recent empirical findings confirm a positive relationship between wages and academic achievement, as measured by test scores, in both developed and developing countries (Glewwe \& Kassouf, 2012). Based on these findings, if malnutrition does indeed hamper school performance, then economic growth and improved nutrition are mutually reinforcing, supporting Fogel's (2010) general thesis.

In recent years, early childhood nutrition programs have been increasingly promoted as a way to raise living standards in developing countries (World Bank, 2015), as well as among the U.S. with low economic status (Bowman, 2007). Proponents of such programs indicate that improved diet, particularly in the pivotal first years of life enhances intellectual development and ultimately academic success (Brown \& Pollitt, 2012). Their view is that, in addition to having direct health benefits, early childhood nutrition programs could also be an instrument of education policy. Yet, the evidence in support of this view is surprisingly sparse (Behrman, 2005).

Velarde and Fernandez (2011) also added that the impact of Conditional Cash Transfer (CCT) in improving the education and health outcomes could aid and support beneficiaries in regularly attending school. CCT programs are also intended to fill gaps in the educational and health outcomes among children, aside from providing them with immediate poverty relief and attending their classes regularly. The Pantawid Pamilyang Pilipino Program, like other Conditional Cash Transfers, employed for varied but interrelated purposes today, has proven to have an impact on education, either directly, using the educational and health grants of the program, or indirectly, by uplifting the total human condition of its recipients.

The study of Montilla (2015) revealed from student responses that they eat their meals three times a day and have considered, as help from the financial support given by the CCT, to buy their daily food from the Php500 per month for educational grants (DSWD, 2009). Pupils responded that their parents/guardians are capable of supplying their regular school allowance. The findings of the National Food and Services Management Institute (2001) presents that those school-age children who eat breakfast do better at attending class regularly than those with no breakfast.

A similar study was conducted with around $72 \%$ of respondents answering that they spend at least P200 on daily meals, and the majority of them say their food budget only partly covers three meals per day. Based on the result, the DSWD said the 4Ps program is "on track in achieving its goal of empowering poor families including the improvement of their nutritional status." However, the National Nutritional Survey (2010) revealed that many Filipinos whether beneficiaries of government assistance programs or not- still suffer from undernutrition. Accordingly, the results revealed that pupils are excellently benefited by 4 Ps in terms of their nutrition having a positive outcome on their school attendance.

Education Grants. Metz (2015) provided that as a solution to the stubbornly persistent problems of chronic absenteeism and lagging students' achievement, New York City provides 52 million dollars to launch 45 community schools throughout the city. These are paired with 25 community-based organizations to provide much-needed wraparound social services for students.

Metz (2015) further stated that schools are stronger when they are paired with community partners. These organizations can bring targeted resources to answer the specific needs of students and families at a particular school.

Also, the New Mexico Higher Education Department (2018) pronounces the primary work is to provide residents with funding for in-state higher education. However, a few of the state-funded programs help students who attended schools out-of-state or assist students from out-of-state in attending schools. The effort is to ensure that more residents are assisted in having higher education necessary to compete in the global market. However, only a few private schools are covered as most programs that are funded are at public colleges and universities.

The area of education is one of the most underfunded in South Africa. Schools and their staff often do 
not have enough money to pursue all the activities and training they like and banks do not lend money for educational purposes. As for college and graduate school students who need to cover increasing tuition, they can borrow money, but the terms for paying it back are not the best. That is why educational grants are so helpful (Zimmerman \& Schunk, 2007).

The students' ability to find ways to finish their studies matters. As Chin (2008) defines it, education refers to how students deal with their studies and how they cope with or accomplish different tasks given to them by their teachers. It is the ability to study and remember facts and being able to communicate the knowledge verbally or down on paper.

Adebayo (2015) concurred that good academic performance is also linked to having good organizational skills such as a tidy place to work and good time management. The study of Florencio (2010) also revealed that the pupils, parents, school heads, and teachers had a positive conceptualization of the role of health and nutrition in schoolrelated behavior such as absenteeism, dropping out and failure.

Several states, as reported by National Center for Education Statistics (2010), have their grant programs. Some of these are student-specific while others are aimed to help students engage in a particular category of education. Income from state lotteries, with a portion of the revenues directed specifically toward assistance with higher education costs, are the sources of these funds.

In California, the California Student Aid Commission (2012) administers the California Cal Grant Program. With these, thousands of students receive grant awards annually. To avail, students should qualify in terms of the GPA and the amount of assistance for tuition. Also, the students should have been enrolled in high school or have graduated with a GPA that merits enrollment in a qualifying university, college, or community college program. Because it is a state program, the amount that will be awarded varies depending on the annual state budget voted on by the California legislature. The grant amount will differ from one school to the next because some of these awards will pay for tuition only, while others will cover room and board, books, and other supplies (Savidge, 2018).

Further, Kane (2003) has proven that additional financial aid has a great impact on students' decisions even when provided late in the process. He also added that financial aid applicants were 3 to 4 percentage points more likely to enroll in college as a result of the recipient of a Cal Grant award.

The Florida Department of Education in the Office of Student Financial Assistance gives out grants to students who attend a university or participate in college in the state of Florida. Another case is that of the Florida Public Student Assistance Program (FSAG) that offers different amounts to students who will attend institutions that are accredited and classified as eligible, and these schools must be participants in the Federal Pell Grant program. The Florida Department of Education also offers the Private Student Assistance Grant Program offers monetary grants for those attending a nonprofit independent university or college (Florida Public Student Assistance Program (FSAG), 2018).

In Massachusetts, students are informed about several grant programs available through the Massachusetts Office of Student Financial Assistance (OSFA). The said office delivers the latest information on student financial aid directly to the Massachusetts Board of Higher Education (Behrman, Parker \& Todd, 2005).

Another popular grant program, Tuition Assistance Program (TAP), is based in New York. It offers up to $\$ 5,000$ and is available to all undergraduate students. High school graduates with a minimum GPA of 2.0 have to submit a Free Application for Federal Student Aid (FAFSA). They should have family earnings that do not exceed what is allowed, and should also be residents of New York (New York State, 2018).

The Pennsylvania State Grant Program has encouraged high school graduates to apply for college grant money. Those students who demonstrate financial need, have their diploma, have been accepted into college or university that is approved by the Pennsylvania Higher Education Assistance Agency (2018). It also provides that these students will be attending classes at least half-time and will be receiving at least 50 percent of their instruction in a classroom setting. Students who were awarded grants through the state will expect to receive approximately 36 percent of the tuition costs for a state college when the family income is between $\$ 75,000-100,000$ annually. This figure rises considerably for lower-income families.

The mentioned states are some of the states that provide for the education of their constituents. Dee (2011) supports that: nearly every state has an extensive grant program offering several different packages based on financial need and other factors. Accessing the website www.nassgap.org/links gives the students and their families complete links to every state/government student grant program. This is a starting point for researching the different grants offered throughout the country by the individual state governments.

However, Naylor (2016) contends that the costs of implementing attendance management are significant and may not result in savings. That is, attendance management could be counter-productive and incur increased costs, in that it may show some short-term cost reduction but incur long-term costs.

At present, the Conditional Cash Transfer of Education Grants in the Philippines is widely availed of by the 4Ps beneficiaries. It was conceived based on the conditional cash transfer programs in Latin American and African countries which have been proven successful as a poverty 
reduction and social development measure (Curry, Cadiogan, \& Giugliano, 2013).

\section{Students' School Attendance}

Students' school attendance is one of the most powerful ways for students' success both in school and in life. When students' school attendance is a priority, it helps students to get better grades, develop healthy life habits, avoid dangerous behavior and have a better chance to graduate from school (Campaign Partners, 2019). However, when students are absent for fewer days, their grades are struggling in school, resulting in failure of grades and eventually to not continuing in school (Education and Social Care, 2016).

Students' school attendance replicates the degree to which schools, communities, and families sufficiently address the essentials of young children (Attendance Works, 2018). Students' school attendance is progressive when schools provide a rich engagement learning experience, have constant experienced and skilled teachers, and actively engage parents in their children's education (Australian Curriculum Assessment and Reporting Authority, 2016).

Bukoye \& Shegunshi (2016) add that students' chronic absences decrease when schools and communities actively and consistently communicate to all students and their parents and reach out to families when their children begin to show patterns of excessive absences. To this, Education and Social Care (2016) confirms that students' school attendance suffers when families are struggling to keep up with the routine of school despite the lack of reliable transportation, long working hours in poorly paid jobs with little flexibility, unstable and unaffordable housing, inadequate health care and escalating community violence. At the same time, communities, according to Campaign Partners (2019), can help lower chronic absences by providing early childhood experiences that help prepare children and families for entry into formal education.

Benhassine, Devoto, Duflo, \& Dupas, (2010) and Garcia \& Hill (2009) disclose that Conditional Cash Transfer Programs (CCTs) have been shown to influence households' investment decisions regarding education and increase students' school attendance. One potential drawback of CCTs is sending children to school to receive the transfer. Moreover, targeting and conditionality can also lead to the exclusion of the poorest segments of the population: targeting systems be imperfect, often excluding many poor households; and imposing conditionality means that those who cannot meet the requirements do not receive any benefit.

Conditional cash transfer programs in education have shown to be successful in Latin American countries, and are increasingly perceived as being effective in increasing students' school attendance (María, Mariana, \& Santiago, 2017). Well-known programs that follow this approach include the Progresa (now called Oportunidades) in Mexico, Bolsa Escola and Bolsa Familia in Brazil, Red de Proteccion Social in Nicaragua, Programa de Asistencia Familiar in
Honduras, Program of Advancement through Health and Education in Jamaica, Food-for-Education in Bangladesh, and Subsidio Unico Familiar in Chile (de Janvry, Finan, Sadoulet, \& Vakis, 2006).

The special attention provided by these programs to older children, at least in terms of subsidy amount, draws from the fact that there is a greater opportunity cost for older children to go to school. In Mexico, the data for 2000 shows that children start to drop out when they reach middle school (New Mexico Higher Education Department, 2018). The rate goes lower as children get older. Hence, the Oportunidades assists the third grade in elementary up to a senior year in secondary.

Meanwhile, Jacobsen, Meeder \& Voskuil (2016) suggested that being in school consistently is important to ensure children gain a strong foundation for subsequent learning. Research also shows that children, regardless of gender, socioeconomic status, or ethnicity, lose out when they are chronically absent. Reimers, Da Silva, Treviño, \& Institut de Statistique de l'Unesco (2006) conclude that the educational theories of the cash transfer programs in Colombia, Honduras, Malawi, Mexico, and Nicaragua are all intended to increase students' school attendance.

While conditional cash transfers (CCTs) have been demonstrated to have substantial short-term impacts on students' school attendance in education, there is evidence on whether their short-term educational impacts translate into a longer-term benefit. Researchers conducted a long-term follow-up survey with households that benefited from a national CCT program in Nicaragua that took place from 2000-2003. They found that seven years after households stopped receiving cash transfers, school attendance of students that benefitted from the program at ages with a high risk of drop-out shows substantial sustained gains in learning outcomes (Barham, Macours, \& Maluccio, 2011).

In 2007, the Philippines piloted a CCT program in four provinces, and since January 2008 has implemented this program nationwide (DSWD, 2009). The priority of the Department of Education is to improve students' school attendance rates that reflect the findings of international research which demonstrate a strong correlation between students' learning and attendance at school (Fernandez, 2015). That is why, educational grants are so helpful (Zimmerman \& Schunk, 2007). Thus, Benhassine, Devoto, Duflo, \& Dupas, (2010) attest that Conditional Cash Transfers (CCTs) have been shown to increase investments in education.

In addition, Fernandez (2015) stated that student school attendance is one of the conditions that the 4Ps recipients have to give particular attention to. Specifically, 4Ps recipients are observed at least $80 \%$ of the required school days. The Department of Social Work and Development sees to it that the parents comply with this condition by keeping track of the students' school attendance. A proof of this would 
be the form which the teachers have to accomplish concerning the department of the 4Ps student-recipients (Manasan, 2011).

The conditionality on the students' school attendance is the most visible and most felt benefit derived from the implementation of the Pantawid Pamilyang Pilipino Program (4Ps). According to teachers, there were lesser absences of students because parents encouraged their learners to be always in school or else they might not meet the attendance threshold per month (Bauer, 2018). It has also been noted that because parents were more informed and more careful in the health condition of their children, lesser pupils became sick leading them to be absent from their classes. Also, students' academic performance was noted to have improved because of their attendance in their classes. Thus, Velarde \& Fernandez (2011) emphasized that the contribution of 4Ps in improving students' school attendance in education can help beneficiaries attain a better quality of life in the future.

\section{Theoretical Framework}

The Stimulus-Response Theory of Skinner (1948) provides the base for this study. It posits that a person's behavior is being manifested as a result of the interplay between stimulus and response. The stimuli like Education Grants and Health Grants given to the 4Ps beneficiaries elicit a response like being always present in their classes.

This is supported by the theory of Operant Conditioning of Thorndike (1905) which behaviors are performed. Such behavior is sustained by reinforcement or rewards, and these are what drive one's behavior. In this study, the 4Ps beneficiaries are being monitored quarterly to see to it that they have complied with the requisites being asked by the program. Thus, Operant Conditioning takes place by rewarding a certain behavior or withholding reward for undesirable behavior. This theory explains how actions are acquired followed by reinforcements that are strengthened and more likely to occur again in the future. Hence, an association is made between this behavior and its consequences. In the Conditional Cash Transfer (CCT) Program, Education and Health Grants are given to the beneficiaries provided that they comply with certain conditions to continue receiving cash grants.

McLeod (2015) reinforces Skinner's Theory, explaining complex human behavior and believing that the best way at understanding behavior

was looking at the causes of an action and its consequences.

Moreover, Konishi (2015) of World Bank Country strengthens the above underpinnings by stating that poor and vulnerable households who received the grants are significantly affected their lives by keeping the poor children in school. Thus, these children are visibly seen in their classrooms which yielded high ratings in terms of their attendance.
On the other hand, Yemtsov (2015) of The State of Social Safety Nets 2015, states that more than 1.9 billion people in 136 low and middle-income countries benefit from social safety net programs. The reports mentioned that the CCT caused a boost in school enrollment and attendance.

\section{Conceptual Framework}

This study investigates the relationship between health and education grants to the Student attendance of the 4Ps beneficiary students. Also, it focused on determining which independent variables significantly contribute/s to the improvement of 4Ps beneficiary students.

It is conceptualized that the independent variable is the implementation of the Conditional Cash Transfer (CCT) Program indicated by health grants and education grants. Health Grants, in this study, is social assistance, to provide cash assistance to the beneficiaries to alleviate their primary needs especially on health like deworming, free medical and dental check-up, weight monitoring, and other benefits related to health. On the other hand, Education Grants, refers to the provision of cash assistance for school allowance, fees, and contributions, for buying school projects and requirements, clothing and school supplies, and other benefits like free training and seminars for livelihood.

Moreover, this study expects to come up with findings on the possible indicator under the independent variable which significantly influences the student's school attendance of the 4Ps students' beneficiaries in Don Vicente Romualdez National High School.

Figure 1.1. shows the conceptual paradigm of the study.

Independent Variable Dependent Variable

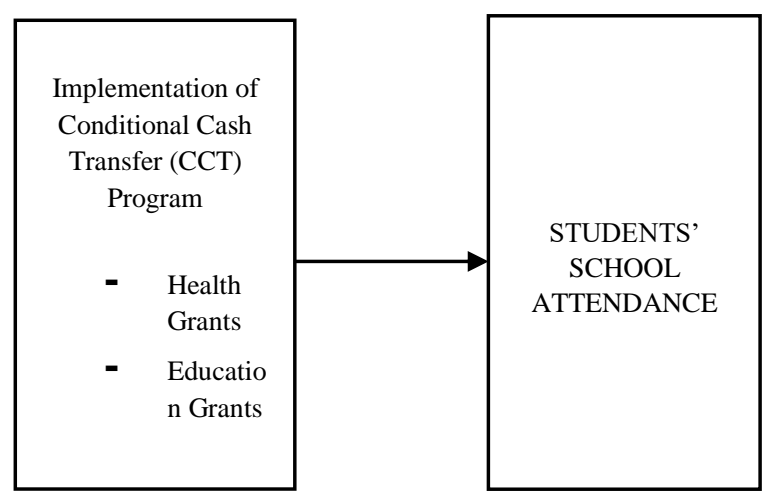

Figure 1.1 Conceptual Framework showing the variables of the study

\section{Statement of the Problem}

This study aimed to find out the significant relationship between the implementation of the 4Ps conditional cash transfer program of health and education to the students' school attendance in Don Vicente Romualdez National High School, Compostela Valley Division. questions: 
1. What is the Implementation of CCT programs in terms of:

\subsection{Health grant; and \\ 1.2. Education grant?}

2. What is the status of school attendance of the 4Ps studentbeneficiaries?

3. Is there a significant relationship between the implementation of CCT and the school attendance of the 4Ps student-beneficiaries?

Null Hypothesis

In this study, the null hypothesis was tested at a 0.05 level of significance:

Ho: There is no significant relationship between the implementation of CCT and the student's school attendance of the 4Ps beneficiaries in Don Vicente Romualdez National High School.

\section{METHOD}

This chapter represents the research design, research subject, research instrument, data gathering procedure, and the statistical tools used in computing the gathered data.

\section{Research Design}

The descriptive-correlational design of the research was utilized in this study. According to Gray (1992), descriptive-correlational research combines both descriptive and correlational designs. This design involves collecting data to test the hypothesis or answer questions concerning the current work status of participants in the study. Descriptive research determines and reports the way things are and attempts to determine the existence and the degree of a relationship between two or more quantitative variables. The purpose of correlational research is to establish a relationship or to use relationships in making a prediction. The relationship therefore of the implementation of CCT and students' school attendance is investigated in this study.

Such design was utilized in this study to determine the relationship, specifically the health and nutrition and school attendance of 4Ps student-beneficiaries in Don Vicente Romualdez National High School, Laak District.

\section{Research Respondents}

year 2017-2018 at Don Vicente Romualdez National High School, Laak, Compostela Valley Province. The school is situated in the area of Laak, Compostela Valley Province. Table 2.1 shows the distribution of 4Ps beneficiary students and teacher respondents. Details of the total respondents are presented below:

The study employed a systematic random sampling technique in selecting the sample wherein Sloven's formula was used in considering the number of 4Ps beneficiaries. In Don Vicente Romualdez National High School, there are six- year levels from grade seven to grade twelve. This school has a total of 254 identified 4Ps student-beneficiaries who are considered as respondents. These include 63 from Grade 7, 50 from Grade 8, 45 from Grade 9, 48 from Grade 10, 27 from Grade 11, and 21 from Grade 12.

\section{Research Instruments}

The data needed for this research were gathered through the use of a researcher-made questionnaire validated by a panel of experts. Several references were read thoroughly to come up with rich details of literature which enlightened the researcher to come up with the survey questionnaire using the Five-point Likert Scale. The questionnaire has two parts. The first part is the profile of the respondents. The second part generates information on health and nutrition and education. The first component consists of 8 item statements and the second part consists of 9 item statements, yielding to

Table 2.1 Distribution of the respondents of the study

\begin{tabular}{|c|c|c|c|}
\hline Year level & $\begin{array}{c}\text { The } \\
\text { population of } \\
\text { 4Ps } \\
\text { beneficiaries }\end{array}$ & $\begin{array}{c}\text { Sample of 4Ps } \\
\text { beneficiaries }\end{array}$ & $\begin{array}{c}\text { Percentage of } \\
\text { 4Ps } \\
\text { beneficiaries }\end{array}$ \\
\hline Grade 7 & 126 & 63 & $24.80 \%$ \\
\hline Grade 8 & 100 & 50 & $19.68 \%$ \\
\hline Grade 9 & 90 & 45 & $17.72 \%$ \\
\hline Grade 10 & 96 & 48 & $18.90 \%$ \\
\hline Grade 11 & 54 & 27 & $10.63 \%$ \\
\hline Grade 12 & 42 & 21 & $8.27 \%$ \\
\hline TOTAL & $\mathbf{5 0 8}$ & $\mathbf{2 5 4}$ & $\mathbf{1 0 0 \%}$ \\
\hline
\end{tabular}

a total of 28 items. The questionnaire has undergone content validation by experts in the field. In the revision, the suggestions of the experts were taken into consideration. After the validation, the instrument was also pilot tested on students who were not part of the study. Cronbach Alpha revealed an acceptable result of 0.82 .

In evaluating the implementation of CCT programs, the following with their perspective range of means and descriptions are considered:

\begin{tabular}{|l|l|l|}
\hline & $\begin{array}{l}\text { Descriptive } \\
\text { Equivalent }\end{array}$ & Interpretation \\
\hline $4.51-5.0$ & Very High (VH) & $\begin{array}{l}\text { The item embodied is } \\
\text { observed at all times }\end{array}$ \\
\hline $3.51-4.5$ & High (H) & $\begin{array}{l}\text { The item embodied is } \\
\text { observed most of the times }\end{array}$ \\
\hline $2.51-3.5$ & Average (A) & $\begin{array}{l}\text { The item is embodied in an } \\
\text { interval occasion }\end{array}$ \\
\hline $1.51-2.5$ & $\begin{array}{l}\text { Below Average } \\
\text { (BA) }\end{array}$ & $\begin{array}{l}\text { The item is embodied is } \\
\text { almost not observed }\end{array}$ \\
\hline $0.50-1.5$ & Poor (P) & The item is never observed \\
\hline
\end{tabular}

In determining the status of school attendance of the 4Ps beneficiaries, the following were used: 


\begin{tabular}{|l|l|l|}
\hline Range of Means & $\begin{array}{l}\text { Descriptive } \\
\text { Equivalent }\end{array}$ & Interpretation \\
\hline $90-100$ & Very High (VH) & $\begin{array}{l}\text { Exceeds the minimum } \\
\text { requirement as mandated by } \\
\text { the CCT Program }\end{array}$ \\
\hline $80-89$ & $\begin{array}{l}\text { High (H) The } \\
\text { minimum }\end{array}$ & $\begin{array}{l}\text { requirement as mandated by } \\
\text { the CCT Program }\end{array}$ \\
\hline $70-79$ & $\begin{array}{l}\text { Average (A) The } \\
\text { average }\end{array}$ & $\begin{array}{l}\text { requirement as mandated by } \\
\text { the CCT Program }\end{array}$ \\
\hline $60-69$ & $\begin{array}{l}\text { Below Average } \\
\text { (BA) }\end{array}$ & $\begin{array}{l}\text { The below average } \\
\text { requirement as mandated by } \\
\text { the CCT Program }\end{array}$ \\
\hline 59 and Below & $\begin{array}{l}\text { Poor (P) The } \\
\text { minimum }\end{array}$ & $\begin{array}{l}\text { requirement as mandated by } \\
\text { DepEd the CCT Program }\end{array}$ \\
\hline
\end{tabular}

Data Gathering Procedures

In gathering the data for this study, a letter was sent to the Department of Education Division of Compostela Valley for the approval of the conduct of the study to the identified secondary school in the district. The approved letter from the division was attached to the letter which was sent to the identified secondary school to request approval for the distribution of the questionnaire.

During the distribution, the researcher explained the reason for the conduct of the study. The researcher personally administered the questionnaire. Instructions as to the mechanics were given. The respondents were given enough time to answer so the questionnaires were retrieved after two weeks.

The responses were then tallied and tabulated and subjected to statistical treatment. Findings were then analyzed and interpreted to provide answers to the research questions asked in the previous section.

\section{Data Analysis}

The following statistical tools were used:

Percentage. This tool was used to determine the percentage distribution of the respondents.

Mean. This tool was used to determine the significant relationship of implementing 4Ps conditional cash grants of the 4Ps student-beneficiaries in Don Vicente Romualdez National High School and students' school attendance.

Pearson r. This tool was used to determine the significant relationship between the implementation of conditional cash transfer and students' school attendance of 4Ps student-beneficiaries in Don Vicente Romualdez National High School.

\section{RESULTS AND DISCUSSION}

This chapter presents the results and discussion of the research problems in this study based on the following: the Implementation of CCT programs in terms of Health, the
Implementation of CCT programs in terms of Education, and the status of school attendance of the beneficiaries. The interpretation of the data collected in the study is also presented in this chapter. Results and findings of the study are presented in a textual and tabular manner along with the mean scores, descriptive interpretations, and implications.

\section{Ps Conditional Cash Transfer (CCT)}

\section{Grants in terms of Health}

The implementation of Conditional Cash Transfer (CCT) Grants was evaluated in terms of Education Grants and Health Grants. Table 3.1 shows the implementation of CCT programs in terms of Health grants.

Based on the result, among the indicators of health, being given deworming pills got the highest rating of 4.83 with the description of very high. This means that this condition was observed at all times.

The result implies that the health program gave respondents the chance to lead healthy living and become productive in terms of school performance. This shows that the CCT Grants in terms of health are substantial. The student-beneficiaries also believed that they should accept

Table 3.1: Implementation of 4Ps Cash Grants in terms of Health

\begin{tabular}{|l|c|c|}
\hline \multicolumn{1}{|c|}{ Item } & Mean & Description \\
\hline 1. being given de-worming pills. & 4.83 & Very high \\
\hline $\begin{array}{l}\text { 2. getting monitored in terms of my weight every } \\
\text { month. }\end{array}$ & 4.61 & Very high \\
\hline 3. eating meals three times a day. & 4.64 & Very high \\
\hline 4. receiving attention to my physical problems. & 4.69 & Very high \\
\hline 5. availing of a dental check-up. & 4.60 & Very high \\
\hline $\begin{array}{l}\text { 6. attending Family Development Sessions on } \\
\text { health and nutrition every month. }\end{array}$ & 4.53 & Very high \\
\hline 7. being given vaccines. & 4.39 & High \\
\hline 8. being able to & 4.40 & High \\
\hline 8.1 buy some food for meals. & 4.25 & High \\
\hline 8.2 avail of medical check-ups. & 4.30 & High \\
\hline 8.3 avail medical assistance & 4.13 & High \\
\hline 8.4 buy snacks during recess time in the school & 4.51 & Very high \\
\hline \multicolumn{1}{|c|}{ Overall } & $\mathbf{4 . 2 6}$ & High \\
\hline
\end{tabular}

Legend: Range of Means Descriptive Equivalent

$\begin{array}{ll}4.51-5.0 & \text { Very High } \\ 3.51-4.5 & \text { High } \\ 2.51-3.5 & \text { Average } \\ 1.51-2.5 & \text { Below Average } \\ 0.50-1.5 & \text { Poor }\end{array}$

without questions about their rules and standards. This is in connection with the idea of Taras and Potts-Datema 
(2005) that establishing a strong connection in health grants contributes to the positive performance of the students.

The other indicators with the same description and observed at all times are receiving attention to physical problems with the mean of 4.69 ; eating meals three times a day with 4.64 and getting monitored in terms of weight every month, 4.61. The items that follow include availing of dental check-up with 4.60; attending Family Development Sessions on health and nutrition every month 4.53, and being able to buy snacks during recess time in the school with 4.51 mean.

The results also generated the conditions that were observed most of the time with the respective means as being given vaccines, 4.39; being able to avail of check-ups, 4.30; being able to buy some food for meals, 4.25; and being able to avail medical assistance, 4.13 .

The overall mean of the Implementation of CCT in terms of Health is 4.26 which is perceived as high among the 4 Ps recipients.

The result implies that the impact of medical checkups, diet, and nutrition in Don Vicente Romualdez National High School manifested behaviors that can interfere with better learning and students attendance whose participation in physical activity tends to perform better on various measures of cognitive performance. Sigfúsdóttir (2007) asserted that children and adolescents whose diets are nutritious and whose participation in physical activity high tend to perform healthier on numerous procedures of cognitive performance and students' school attendance.

Further, it is assumed that the implementation of CCT ensures the idea that Health Grants is important to the 4Ps recipients.

\section{Ps Conditional Cash Transfer (CCT)}

\section{Grants in terms of Education}

Determining the implementation of Conditional Cash Transfer Programs

in Don Vicente Romualdez National High School was one of the objectives of this research. Table 3.2 shows the Implementation of CCT programs in terms of Education. The indicators of Implementation of CCT programs in education reflected an overall mean of 4.40 which indicates $a$ high descriptive equivalent. The result signifies that the implementation of a Conditional Cash Grant in Education is high.

The result indicates that $4 P$ s recipients are being given daily school allowances as shown by the mean score of 4.83 reflected by very high description. This is followed by being able to attend classes regularly with a mean score of 4.69 described as very high. This implies that the Conditional Cash Transfer program was strictly manifested and implemented. Shown in Table 2.2 is the implementation of conditional cash transfer grants in terms of Education. These results are manifested as having paid the school fees and contribution with a mean of 4.61; being provided with school requirements and projects with a mean of 4.64; being able to buy school supplies

Table 3.2 Implementation of 4Ps Cash Grants in terms of Education

\begin{tabular}{|l|c|c|}
\hline \multicolumn{1}{|c|}{ Item } & mean & $\begin{array}{c}\text { Descriptio } \\
\text { n }\end{array}$ \\
\hline 1. Being given daily school allowances. & 4.83 & Very high \\
\hline 2. Being able to attend classes every day. & 4.69 & Very high \\
\hline 3. Having paid the school fees/contribution. & 4.61 & Very high \\
\hline $\begin{array}{l}\text { 4. Being provided with school requirements and } \\
\text { projects. }\end{array}$ & 4.64 & Very high \\
\hline 5. being able to. & 4.60 & Very high \\
\hline 5.1. shop. & 4.51 & Very high \\
\hline 5.2. buy shoes. & 4.25 & High \\
\hline 5.3. buy some clothes. & 4.40 & High \\
\hline 5.4. buy school supplies. & 4.53 & Very high \\
\hline 5.5. pay school obligations. & 4.44 & High \\
\hline 5.6. buy for school projects. & 4.39 & High \\
\hline 5.7. pay traveling expenses. & 4.30 & High \\
\hline 5.8. have daily allowance in school. & 4.13 & High \\
\hline $\begin{array}{l}\text { 6. Being encouraged to avoid cutting classes. } \\
\text { 7. Having attended the Sustainable Livelihood } \\
\text { Program (SLP). }\end{array}$ & 4.23 & High \\
\hline $\begin{array}{l}\text { 8. Having attended any training programs for } \\
\text { livelihood provided by DSWD. }\end{array}$ & 4.08 & High \\
\hline $\begin{array}{l}\text { 9. Having availed any livelihood materials } \\
\text { provided from the training. }\end{array}$ & 4.03 & High \\
\hline & $\mathbf{4 . 4 0}$ & High \\
\hline
\end{tabular}

Legend:

Range of Means Descriptive Equivalent

$4.51-5.0$ Very High

$3.51-4.5$

High

$2.51-3.5$

Average

$1.51-2.5$

Below Average

$0.50-1.5$

Poor

and school projects, with means of 4.53 and 4.39, respectively.

Meanwhile, items on being able to buy some clothes with 4.40 and shoes with 4.25; being able to pay for travel expenses with 4.30; having daily allowances with a mean of 4.13; having the courage to avoid cutting classes with 4.23 follow. Other items include: have attended the sustainable

livelihood program with 4.17 , have attended any training programs provided by the DSWD with 4.08 , and have availed any livelihood materials provided from the training with a 4.03 mean. This is the manifestation that 4Ps conditional cash transfer guarantees the accessibility of education grants to enhanced students' attendance through increased coordination of 4 Ps recipients. 
The overall mean of the implementation of CCT in terms of Education is 4.40 which is perceived as High among the 4Ps recipients. This result implies that the student's support through daily allowances has helped them grow and develop with shared responsibilities from parents and teachers. They are expected to become responsible persons in their specific community.

This is in congruence to the idea of Coispeau and Lou (2015) that partnership is important to increase the livelihood of each, achieving their mission to advance their mutual interest. Crawford (2016) supports the findings that there is statistically positive significant effects for cash transfers in education in helping to keep more students attending regular classes. With this, the implementation of conditional cash transfer in education was needed for the recipients to achieve the highest percentage in student's attendance.

More so, Cruz (2015) reported that the DSWD has the authority to conditional cash transfer. Thus, the gross enrollment rate for high school students 12-15 years old was higher for Pantawid Pamilya children living near the poverty threshold. This requires the DSWD personnel with certain

initiatives directly geared towards the improvement of students' attendance. They are specifically tasked to regularly oversee and implement the whole program.

Also, results conform to the Department of Education Order No. 11, s.

1991, sec. 157.1 of the 2010 Revised Manual entitled "Students Attendance and Punctuality" which specified that students' absences should not be more

than twenty percent (20\%) of the prescribed number of class or laboratory periods during the school year. For this reason, the students' attendance in school was strictly monitored. Indeed, DSWD highly emphasized the school attendance of the students that served as the basis in getting the cash grants. Thus, recipient students are getting motivated in attending the class regularly.

\section{Students' School Attendance of 4Ps Beneficiaries}

Table 3.3 shows the status of attendance of the 4Ps student-beneficiaries in Don Vicente Romualdez National High School, SY 2017 - 2018. As shown, it has an overall mean of $98 \%$ with a very high description.

The result implies that 4Ps student-beneficiaries were able to meet the expectation of the school as to their attendance. It has also complied with what is asked of them by the government as part of the requirement for them to continue as beneficiaries in the cash grant.

It is supported by Manasan (2011) that there is a significant improvement in school attendance and is already evident in areas covered by the program. This shows that the number of students in public schools increased.

In connection, Naylor (2016) stated that constant support makes the students productive in their participative performance in class. Velarde and Fernandez (2011) also added that the impact of CCT could aid and support beneficiaries in regularly attending school.

Table 3.3 Status of School Attendance of the 4Ps Student-Beneficiaries

\begin{tabular}{|c|c|c|}
\hline School Attendance & Mean & Description \\
\hline Percentage of Attendance & 98.00 & $\begin{array}{c}\text { Exceeds the minimum } \\
\text { requirement as } \\
\text { mandated by the CCT } \\
\text { Program }\end{array}$ \\
\hline
\end{tabular}

Relationship between Implementation of CCT

Grants and Students' School Attendance of the 4Ps Beneficiaries

Shown in Table 3.4 are the results in the relationship between the implementation of Conditional Cash Transfer (CCT) Programs and students' school attendance. Variables posted the following r-value and p-value results: Health Grants 0.46 with p-value 0.000 and education grants 0.87 with a p-value of 0.000 . Both have significant results.

The result implies that the Health Grants and Education Grants are found to have a significant relationship with the students' school attendance. Thus, the constant support of the Government makes the students progress and improve their standard of living.

In support, Saavedra (2016) claimed that there was considerable evidence that conditional cash grants helped increase the percentage of

Table 3.4 Test of Significance between Implementation of CCT and Students' School Attendance

\begin{tabular}{|c|c|c|c|}
\hline $\begin{array}{c}\text { Dependent } \\
\text { Kariables }\end{array}$ & \multicolumn{3}{|c|}{ School Attendance } \\
\hline $\begin{array}{c}\text { Independent } \\
\text { Variables }\end{array}$ & r - value & p - value & Description \\
\hline Health grants & 0.46 & 0.000 & Significant \\
\hline Education grants & 0.87 & 0.000 & Significant \\
\hline Overall & 0.17 & 0.008 & Significant \\
\hline
\end{tabular}

attendance of learners with more mixed evidence on the effects on learning and quality. If parents and students would cooperate, students would have better remarks and contribute to decreasing the number of drop-outs. The school would further be required to inform parents about school activities and projects. As further highlighted, the ability of the school staff to show respect and genuine care to students increases students' support for school events and contributes to the number of increases in school attendance.

Das (2013) agrees, presenting that a study has found that grants for schools increase students' attendance. Accordingly, findings revealed that students are excellently 
benefited by 4Ps in terms of health and education have a positive outcome on school attendance.

This also coincides with Benhassine, Devoto, Duflo, \& Dupas (2010); Garcia \& Hill (2009) that conditional cash transfer programs (CCTs) have shown influence on households' investment decisions regarding education and increased student school attendance.

Bukoye \& Shegunshi (2016) also supported that students' absences decrease when schools and communities actively and consistently communicate to all students and their parents. Reaching out to families when their children begin to show patterns of excessive absences is important. This would at least help in decreasing the drop-out rates of students.

The result is explained by the theory of Skinner (1948) which states that a person's behavior is being manifested as a result of the interplay between stimulus and response. The stimuli like Education Grants and Health Grants given to the 4Ps student-beneficiaries elicit a response like being always present in their classes. This concurs with the Operant Conditioning theory of Thorndike (1905), which covers the idea of rewarding a certain behavior or withholding a reward for undesirable behavior. In this case, the behavior of coming to school is being rewarded by keeping these studentbeneficiaries in the CCT Grant Program. Further, McLeod (2015) reinforces Skinner's Theory, explaining complex human behavior and believing that the best way at understanding behavior is looking at the causes of an action and its consequences. This concept constitutes the implementation of 4Ps conditional cash grants which include health grants and education grants. It is distinguished based on the directness or conceptual closeness of its relation to students' school attendance.

\section{SUMMARY, CONCLUSION, AND RECOMMENDATION}

Summary of findings, conclusions are drawn from the results' implications of the data, and recommendations are presented in this chapter.

\section{Summary}

The study determined the relationship between the implementation of 4Ps CCT grants of health and education to the school attendance of 4Ps recipients in Don Vicente Romualdez National High School. Specifically, the following results were yielded:

1. Out of 254 beneficiary students respondents, the overall mean of 4.26 for Implementation of CCT programs in terms of health and an overall mean of 4.40 in education.

2. The computed status of attendance of the 4Ps beneficiary students in Don Vicente Romualdez National High School generated an overall mean of $98 \%$.
3. The correlation coefficients between the independent variables to the dependent variable the Extent of Implementation of CCT programs in terms of health $r=0.46$ and the extent of Implementation of CCT programs in terms of education was $\mathrm{r}=0.87$ with an overall mean of 0.17 .

4. The computed correlation between the Implementation of CCT programs in terms of health was 0.46 with a p-value of 0.000 while the extent of Implementation of CCT programs in terms of education was 0.87 with a p-value of 0.000 .

\section{Conclusions}

Based on the findings on the gathered data, the following conclusions were drawn:

1. The Implementation of CCT programs in terms of Health and Education is high. This means that all indicators of the independent variable are perceived and observed very well by the respondents, implying that respondents lead to replicating the behaviors observed. To this, Mo, Zhang, Yi, \& Luo, (2012) confirmed that CCTs can be effective in boosting school enrolment and decreasing school dropout.

2. The status of attendance of 4Ps student-beneficiaries in Don Vicente Romualdez National High School is very high. This implies that the attendance of the 4Ps student-beneficiaries exceeds the minimum requirement as mandated by the CCT Program. This indicates that constant support makes the student productive in their participative performance in class (Naylor, 2016). Crawford (2016) also concluded that there is a significant effect for cash transfers to keep more students attending school regularly. Velarde and Fernandez (2011) further added that the impact of CCT could aid and support beneficiaries in improving students' school attendance.

3. The indicators of the 4Ps Conditional Cash Transfers namely: Health and Education Grants are all below 0.005 level of significance and with the probability values of 0.46 and 0.87 . Thus, the 4Ps CCT significantly influenced the students' school attendance of the 4Ps student-beneficiaries. Therefore, there is a relationship between the implementation of 4Ps Conditional Cash Transfer and students' school attendance of studentbeneficiaries in Don Vicente Romualdez National High School. To this, Skinner (1948) stated that a person's behavior is being manifested as a result of the interplay between stimulus and response. This is also in connection with the concept of McLeod (2015) that the best way at understanding behavior is by looking at the causes of an action and its consequences that are distinguished based on the directness or conceptual closeness.

4. All indicators of 4Ps Conditional Cash Transfer significantly influenced students' school attendance. 
This is supported by Velarde \& Fernandez (2011) that the CCT has helped in improving students' school attendance of the 4Ps student-beneficiaries and eventually attain a better quality of life in the future.

\section{Recommendations}

Based on the findings and conclusions, the following are the recommendations offered by the researcher:

The Philippine Government. The government may consider maintaining and continuing the implementation of 4Ps. It is highly recommended to design an additional program for the beneficiaries who graduated from the CCT. Otherwise, beneficiaries will go back to the same status of life. In the absence of a follow-up program, the purpose of CCT in the Philippines will be defeated.

Department of Social Welfare and Development (DSWD). Being the lead agency in promoting social welfare and development to the community, the DSWD needs to continue and maintain the program and find another source of allocations to increase the conditional cash grants. This is because the funding was not enough for the monthly budget, especially in providing education for the recipients in farflung areas. It is also recommended to have an open forum and dialogue with beneficiaries for every block monthly. The DSWD may also initiate seminars and consultations for the beneficiaries.

Department of Education (DepEd). In line with the significant contributions of students' attendance, the DepEd personnel may consider allocating extra funds for the effective instructional implementation process. Also, educational programs which promote strong relationships between schools and linkages be included.

Community. The community has a greater gain on this program since it will help address the individual needs and cater to the learner in education. The community members have to be continuously involved in sustaining the vital role of secondary schools through increased participation in school activities, particularly in the students' attendance. Strong linkage between school and community is highly recommended since it has a big impact on the students' attendance.

School Administrator. School administrators may consider initiating efforts in acquiring additional learning facilities by tapping the LGUs and NGOs. Further, this may identify the strengths and weaknesses in parental involvement, thus, providing tips on how they can encourage parents to participate actively in the parent-teacher association activities. This is a support to the student attendance of the 4Ps recipients.

Teachers. The teachers may check the attendance of the learners regularly. This is helping them to strengthen their linkage with parents and the community in the actualization of the identified program for learners. Teachers should be challenged to design an alternative program to help parents get involved with the school community. Teachers may resort to positive reinforcements to encourage the students to come to school regularly.

Parents. Parents may consider providing the actual assessment of the status of the students' attendance. This helps them realize the involvement and participation of 4Ps students.

Students. Since they are the main focus of the program, students may consider continuing and striving harder in their studies for the improvement of their lives. Students must also have community involvement at least once a month as the counterpart of the government assistance to feel the essence of receiving the cash grant. This is to ensure that student beneficiaries give the value of what they received.(S. A. McLeod, 2007)

(Skinner, 1971)(Skinner, 1963)(Montilla, 2015)(Curry et al., 2013)(Torre, 2016)(Asia Pacific Journal of Education \& Sciences, 2015; Carbayas, 2012; National Center for Education Statistics, 2010; Torre, 2016, 2016)

(DSWD, 2005, 2008, 2009, 2009, 2009, 2016, 2016; Torre, 2016)

\section{ACKNOWLEDGMENT}

This fruitful endeavor is highly considered a grace from Almighty God, Jesus Christ. The Researcher's human capability cannot make all these things possible without the guidance of the Divine Fate. She is thankful to the Almighty GOD for the wisdom and firmness that He has imparted upon her during the writing process; indeed, throughout her life, she believes: "With God nothing is impossible" (Matthew 19:27).

The Researcher never expected that her thesis writing would be very memorable and significant as she learned many things and gained many friends who truly care. Furthermore, her thesis writing days would not be successful without the following people who exerted efforts and sacrificed their precious time just to help her;

Dr. Reynante A. Solitario, Officer-In-Charge, Office of School Division Superintendent of Compostela Valley, for his kindness in allowing the researcher to conduct the study;

Dr. Eleonor T. Callena, her adviser, for her encouragement, guidance, talent, time, understanding, and wisdom in helping the researcher to finish this endeavor;

Ms. Donna G. Magallanes, for her brilliant recommendations to make the manuscript worthy to read;

Dr. Milagros A. Pedrosa, for her cleverness in the area of research that contributed to the completion of this research;

Dr. Lynnard Bobby Asirit, Dr. Willie Jun R. Broce, and all members of the Technical Working Group of Division of 
Compostela Valley, for the manifested patience in sharing ideas to the researcher that vastly contributed to the completion of this study; for serving as the researcher's mentors since the very first chapter of the researcher's study and for sharing their special skills to make the presentation relevant;

Ma'am Aloha, Sir Redgie, and Sir Jumar, the researcher's classmates, for sharing and cherishing their moments especially the laughter and tears shared; and not leaving anybody behind;

Mrs. Josephine S. Galdo, for lending her time when the researcher asked for help to understand the actual process of the study;

Ma'am Marilou C. Dumagil, for extending her time for cooperating in contributing and giving the accurate data to support for the study needed;

Ma'am Mia Ann A. Suyu and Sir Jerson C. Amante, for letting the researcher borrow a laptop and laptop charger when necessary;

Ma'am Grichel S. Ruedas and Ma'am Marissa P. Juarez, for the encouragement for her to finish her study without hesitation;

Her relatives and friends for the moral support;

Her parents, for the wisdom and encouragement that motivated the researcher; more especially her ever-loving mother for the support in all aspects;

Cyrus, her son, for inspiring her to finish her work without hesitations and limitations;

To all of them who significantly contributed to making this work successful, the researcher is forever indebted. To God be Glory!

- The Researchers

\section{Declaration of Originality}

We, Christilyn J. Arcayna, Jonelyn J. Arcayna, Resty J. Arcayna, declare that this research is original to the best of my knowledge. I declare further that this activity was undertaken by me.

\section{REFERENCES}

[1] Adebayo, F., (2015). Time Magement and Students Academic Performance in Higher Institutions, Nigeria: A Case Study of Ekiti State. Retrieved May 25 2019, from https://pdfs.semanticscholar.org

[2] Asia Pacific Journal of Education, A. \&amp, \& Sciences., (2015). Pantawid Pamilyang Pilipino Program (4Ps): Assistance to Pupil\& Education. Retrieved May 25 2019, from https://www.academia.edu/31116479/Pantawid_Pamilyang_Pilipi no_Program_4Ps_Assistance_to_Pupils_Education

[3] Attendance Works., (2018). 10 Facts About School Attendance. Retrieved May 25, 2019, from Attendance Works website: https://www.attendanceworks.org/chronic-absence/theproblem/10-facts-about-school-attendance/

[4] Australian Curriculum Assessment and Reporting Authority., (2016). Student attendance. Retrieved May 25, 2019, from https://www.acara.edu.au/reporting/national-report-on-schoolingin-australia-data-portal/student-attendance\#View1

[5] Bailey, S., \& Hedlund, K., (2012). The impact of cash transfers on nutrition in emergency and transitional contexts | Overseas Development Institute (ODI). Retrieved May 25, 2019, from https://www.odi.org/publications/6338-impact-cash-transfersnutrition-emergency-and-transitional-contexts

[6] Barham, T., Macours, K., \& Maluccio, J. A., (2011). Long-Term Effects of a Conditional Cash Transfer Program in Nicaragua | The Abdul Latif Jameel Poverty Action Lab. Retrieved May 25, 2019, from https://www.povertyactionlab.org/evaluation/long-termeffects-conditional-cash-transfer-program-nicaragua

[7] Bauer, L., (2018, April 25). School attendance: A building block of student achievement. Retrieved May 26, 2019, from Brookings website: https://www.brookings.edu/blog/upfront/2018/04/25/school-attendance-a-building-block-of-studentachievement/

[8] Behrman, J. R., Sengupta, P., \& Todd, P., (2000). The Impact of Progress on Achievement Test Scores in the First Year. Retrieved May 25, 2019, from https://www.researchgate.net/publication/266472233_The_Impact _of_Progresa_on_Achievement_Test_Scores_in_the_First_Year

[9] Behrman, J. R., Sengupta, P., \& Todd, P., (2005). Progressing through PROGRESA: An Impact Assessment of a School Subsidy Experiment in Rural Mexico. Economic Development and Cultural Change, 54(1), 237-275. Retrieved May 25 2019, from https://doi.org/10.1086/431263

[10] Benhassine, N., Devoto, F., Duflo, E., \& Dupas, P., (2010). Cash Transfers for Education in Morocco | The Abdul Latif Jameel Poverty Action Lab. Retrieved May 25, 2019, from https://www.povertyactionlab.org/evaluation/cash-transferseducation-morocco

[11] Bowman, S., (2007). Low Economic status is associated with suboptimal intakes of nutritious foods by adults in the National Health and Nutrition Examination Survey 1999-2000. Nutrition Research 27(9), 515 - 523,2007. Retrieved May 25 2019, from https://scholar.google.com.ph

[12] Brown, E., \& Pollitt., (2012). Building performance evaluation and certification in the UK: a critical review of SAP. Retrieved May 25 2019, from https://ideas.respec.org

[13] Bukoye, O. T., \& Shegunshi, A., (2016). Impact of Engaging Teaching Model (ETM) on Students' Attendance. Cogent Education, 3(1). Retrieved May 25 2019, from https://doi.org/10.1080/2331186X.2016.1221191

[14] California Student Aid Commission. (2012). General Cal Grant Eligibility Requirements. Retrieved June 6, 2019, from http://www.csac.ca.gov/doc.asp?id=105

[15] Campaign Partners., (2019). The Importance of School Attendance. Retrieved May 26, 2019, from Absences Add Up website: http://absencesaddup.org/importance-of-schoolattendance/

[16] Carbayas, R., (2012). Raising Dependents: The Philippines Pantawid Pampamilyang Pilipino Program (4Ps). PIA Western Mindanao. Retrieved May 25 2019, from https://piazampen.blogspot.com

[17] Cecchini, S. \& Madariaga, A., (2011). Conditional Cash Transfer Programmes:The Recent Experience in Latin America and the Caribbean. Retrieved May 25 2019, from https://papers.ssrn.com

[18] Chin, C., (2008). Students' questions: a potential resource for teaching and learning science: Studies in Science Education. Retrieved June 6, 2019, from https://www.tandfonline.com/doi/full/10.1080/0305726070182810

[19] Chulack, A., (2016). The Importance of Nutrition in Early Childhood Development. Retrieved May 25 2019, from https://novakdjokovicfoundation.org

[20] Coispeau, O., \& Lou, S., (2015). Mergers and acquisition and partnership in China. Singapore: World Scientific. P. 311. ISBN 9789814641029. OCLC 898052215. Retrieved May 25 2019, from https://scholar.google.com.ph

[21] Crawford, L., (2016). Cash Grants for Schools and Pupils can Increase Enrollment \& Attendance Despite Ongoing Conflict: 
Findings from South Sudan. Retrieved May 25 2019, from https://www.googlescholar.com

[22] Cruz, R. G., (2015). DSWD stands by impact of conditional cash transfer. ABS-CBN News Journal. Retrieved May 25 2019, from https://news.abs-cbn.com/nation/09/07/15/dswd-stands-impactconditional-cash-transfers

[23] Curry, M. S., Cadiogan, A. T., \& Giugliano, R. G., (2013). Brazil's BolsaFamilia and the Philippines "4PS" CCT Programs: Considering South-South Cooperation for Social Protection. Retrieved May 25 2019, from www.apssr.com/wpcontent/uploads/ 2018/03/1Curry-091713.pdf

[24] Das, J. K., (2013). Micronutrient fortification of food and its impact on woman and child health: a systematic review. Retrieved May 25 2019, from https://www.ncbi.nlm.nih.gov

[25] De Janvry, A., (2006). EconPapers: Can conditional cash transfer programs serve as safety nets in keeping children at school and from working when exposed to shocks? Retrieved May 25, 2019, from

https://econpapers.repec.org/article/eeedeveco/v_3a79_3ay_3a200 6_3ai_3a2_3ap_3a349-373.htm

[26] De Janvry, A., Finan, F., Sadoulet, E., \& Vakis, R., (2006). Can conditional cash transfer programs serve as safety nets in keeping children at school and from working when exposed to shocks? Journal of Development Economics, 79(2), 349-373. Retrieved May 25 2019, from https://doi.org/10.1016/j.jdeveco.2006.01.013

[27] Dee, T. S., (2011). Conditional Cash Penalties in Education: Evidence from the Learnfare Experiment. Economics of Education Review, 30(5), 924-937. Retrieved May 25 2019, from https://doi.org/10.1016/j.econedurev.2011.05.013

[28] Denny, M.,(2004). The impact of NCLB and the reauthorization of IDEA on academic instruction of students with emotional or behavioral disorders. Retrieved May 25 2019, from http:www.journals.sagepub.com/doi/abs/10.1177/0198 74290402900307

[29] Department of Social Welfare and Development, (2005). Process Evaluation of FDS: Pantawid Pamilyang Pilipino Program. $\begin{array}{llll}\text { Retrieved } & \text { May } & 25 & 2019,\end{array}$ https://www.pantawid.dswd.gov.ph $>20$

[30] Department of Social Welfare and Development, (2008). Philippine Conditional Cash Transfer Program Impact Evaluation. Retrieved May 25 2019, from https://www.dswd.gov.ph

[31] Department of Social Welfare and Development, (2009). Conditional Cash Transfer (CCT) Philippines:Improving the Human Capital of the Poor (Pantawid Pamilyang Pilipino Program or 4Ps). 4Ps Concept Paper for MCC. Retrieved May 25 2019, from

http://unpan1.un.org/intradoc/groups/public/documents/ungc/unpa n040549.pdf

[32] Department of Social Welfare and Development, (2016). Children For Adoption Whose Families Are Beneficiaries of Pantawid Pampamilyang Pilipino Program. Retrieved May 25 2019, from https://www.dswd.gov.ph

[33] Eamon, M.K. \& Zuehl, R., (2001). Four P's (Pantawid Pampamilyang Pilipino Program):It's Effect on the Academic Performance of Beneficiaries. Retrieved May 25 2019, from https://www.studymode.com

[34] Education and Social Care, (2016). Student Attendance and Absence. Retrieved May 25 2019, from https://googlescholar.com

[35] Estabillo, A. V., (2011). 74,000 families in R-12 get cash from 4Ps. Retrieved May 25, 2019, from MindaNews website: https://www.mindanews.com/top-stories/2011/07/74000-familiesin-r-12-get-cash-from-4ps/

[36] Fernald, L. C. H., Gertler, P. J., \& Neufeld, L. M., (2008). Role of cash in conditional cash transfer programmes for child health, growth, and development: an analysis of Mexico's Oportunidades. Lancet (London, England), 371(9615), 828-837. Retrieved May 25 2019, https://doi.org/10.1016/S0140-6736(08)60382-7

[37] Fernandez, M. B., (2015). Effectiveness of the School Attendance Improvement Plan in Increasing The Attendance Rate of 4Ps Recipients of Dulag National High School. Retrieved May 25 2019 ,
https://www.academia.edu/33419298/ACADEMIC_PERFORMA NCE_OF_THE_STUDENTS_WHO_ARE_4PS_BENEFICIARIE S_A_Research_Proposal

[38] Florencio, A., (2010). DBM Abad: Aquino CCT Program Timely, Responsive, Improved Not Only Cash Transfer but "Complete Comprehensive Package." Retrieved May 25 2019, from https://www.officialgazette.gov.ph

[39] Florida Public Student Assistance Program (FSAG), (2018). Florida Department of Education Office of Student Financial Assistance State Scholarship and Grant Programs. 1314, Tallahassee, Florida. Retrieved May 25 2019, from https://www.floridastudentfinancialaidsg.org

[40] Garcia, S., \& Hill, J. L., (2009). Impact of condtional cash transfers on children's school achievement: evidence from Colombia | Request PDF. Retrieved May 25, 2019, from https://www.researchgate.net/publication /227618258_Impact_of_condtional_cash_transfers_on_children's_ school_achievement_evidence_from_Colombia

[41] Garza, M., \& Villarreal, H. J., (2007). Do Conditional Cash Transfers Affect Poor Students' Performance? 25. Retrieved May 25, 2019, from https://www.researchgate.net/publication

[42] Garza, R., \& Huerta, M. E., (2014). Latino High School Students' Perceptions of Caring: Keys to Success. Journal of Latinos and Education, 13, 134-151. Retrieved May 25 2019, https://doi.org/10.1080/15348431.2013.821065

[43] Glewwe, P., \& Kassouf, A. L., (2012). The Impact of the Bolsa Escola: Familia conditional cash transfer program on enrollment, dropout rates and grade promotion in Brazil. Retrieved May 25 2019 ,

from http://www.scientificdirect.com/science/article/pii/S03043878110 00538

[44] Higher Educational Aids Board, (2015). Higher Educational Aids Board. Retrieved May 25 2019, from https://www.heab.state.wi.us

[45] Hillman, N. W., (2013). College on Credit: A Multilevel Analysis of Student Loan Default. The Review of Higher Education, 37(2), 169-195. https://doi.org/10.1353/rhe.2014.0011

[46] Jacobsen, K., Meeder, L., \& Voskuil, V. R., (2016). Chronic Student Absenteeism: The Critical Role of School Nurses. NASN School Nurse, 31(3), 178-185. Retrieved May 25 2019, from https://doi.org/10.1177/1942602X16638855

[47] Jensen, E., (2009). Teaching with Poverty in Mind: What Being Poor Does to Kids' Brains and What Schools Can Do About It. Retrieved May 25 2019, from https://eric.ed.gov

[48] Jyoti, D., Frongillo, E., \& Jones, S., (2005). Food insecurity affects school children's academic performance, weight gain, and social skills. Journal of Nutrition, 135 (12), 2831 - 2839. Retrieved May 25 2019, from https://www.foodnutrition_academic_children/journal-nutrition

[49] Kane, T., (2003). A Quasi-Experimental Estimate of The Impact of Financial Aid on College-Going. Retrieved May 25 2019, from https://www.siteresources.worldbank.org

[50] Konishi, M., (2015). World Bank hails Philippines CCT Program. Retrieved May 25 2019, from https://www.sunstar.com.ph

[51] Lange, F., \& Topel, R., (2004). The Social Value of Education and Human Capital. 70. Retrieved May 25, 2019, from https://www.researchgate.net/publication

[52] Lavinas, L., (2001). Bottom-up Policy Diffusion: National Emulation of a Conditional Cash Transfer. Retrieved May 25 2019, from https://www.jstor.org

[53] Lindert, K., Skoufias, E., \& Shapiro, J., (2006). Redistributing Income to the Poor and the Rich: Public Transfers in Latin America and the Caribbean.

[54] Manasan, R. G., (2011). Pantawid Pamilyang Pilipino Program and School Attendance: Early Indications of Success. Philippine Institute for Development Studies. Retrieved May 25 2019, from http://serpp.pids.gov.ph/download.php?=5023 8s=1

[55] María, E., Mariana, M., \& Santiago, G., (2017). Compulsory Education Laws or Incentives from Conditional Cash Transfer Programs: Explaining the Rise in Secondary School Attendance Rate in Argentina. Education Policy Analysis .Retrieved May 25, 2019, from https://eric.ed.gov/?id=EJ1148693 
[56] McLeod, S. A., (2007). Bf skinner: Operant conditioning. Retrieved September, 9, 2009, from http://googlescholar.com

[57] Metz, C., (2015). New York Teacher Issue: New Community schools get grants to boost attendance. New York Teacher Issue. Retrieved May 26, 2019 from https://www.uft.org

[58] Mo, D., Zhang, L., Yi, H., \& Luo, R., (2012). School Dropouts and Conditional Cash Transfers: Evidence from a Randomized Controlled Trial in Rural China's Junior High Schools. Journal of Development Studies, 49, 190-207.Retrieved May 26, 2019, from https://doi.org/10.1080/00220 388.2012.724166

[59] Montilla, M. M., (2015). Academic Performance of students who are 4Ps. Retrieved May 26, 2019, from https://www.academia.edu.ph

[60] Montilla, M. M., Delavin, E. A., \& Villanueva Jr, R. M., (2015). Pantawid Pamilyang Pilipino Program (4Ps): Assistance to Pupil's Education. Asia Pacific Journal of Education, 2(3), 5. Retrieved May 26, 2019, from https://PantawidPamilyangPilipinoProgram(4Ps)Assista.pdf

[61] National Center for Education Statistics, (2010). College Grants For High School Students. Retrieved May 26, 2019, from https://www.collegegrants.org

[62] National Food Service Management Institute (NFSMI), (2001). Nutrition and Cognitive Development, Mealtime Memo for Child Care. The University of Mississipi, 2001. Retrieved May 26, 2019 , from http://www.nfsmi.org

[63] National Nutritional Survey, (2010). National Reports and Surveys Health Promotion Board. Retrieved May 26, 2019, from https:www.hpb.gov.sg

[64] Naylor, C., (2016). Attendance management in BC's K-12 public education system. Retrieved May 26, 2019, from http:www.googlescholar.com

[65] New Mexico Higher Education Department (NMHED), (2018). New Mexico Commission on Higher Education Dashboard. Retrieved May 26, 2019, from https://www.hed.state.nm.us

[66] New York State, (2018). The New York State Tuition Assistance Program. Higher Education Services Corporation. New York. Retrieved May 26, 2019, from https://www.hesc.ny.gov

[67] Pennsylvania Higher Education Assistance Agency (PHEAA), (2018). Pennsylvania State Grant Program. Pennsylvania State Program 2018-19 Program Manual. Retrieved May 26, 2019, from https://www.pheaa.org

[68] Reimers, F., Da Silva, C. D., Treviño, E., \& Institut de statistique de l'Unesco., (2006). Where is the "Education" in conditional cash transfers in education? Montreal: UNESCO Institute for Statistics.

[69] Reyes, C. M., Tabuga, A. D., Mina, C. D., \& Asis, R. D., (2013). Promoting Inclusive Growth Through the 4Ps. Retrieved May 26, 2019,

from

https://s3.amazonaws.com/academia.edu.documents/rev.pdf?AWS AccessKeyId=AKIAIWresponse-contentdispositionPhilippine_Institute_for_Development_Stu.pdf

[70] Saavedra, J. E., (2016). The Effects of conditional cash transfer programs on poverty reduction, human capital accumulation and wellbeing. Retrieved May 26, 2019, from https://www.un.org/esa/socdev/egms/ docs/2016/PovertySDGs/JuanSaavedra-paper.pdf

[71] Savidge, N., (2018). California Student Aid Commission backs expansion of Cal Grant program. Retrieved June 6, 2019, from https://edsource.org/2018/california-student-aid-commissionbacks-expansion-of-cal-grant-program/605486

[72] Sigfúsdóttir, M.H., (2007). Health Behavior and Academic Achievement in Icelandic school. Retrieved May 26, 2019, from http://www.ncbi.nlm.nih.gov

[73] Skinner, B. F., (1948). Superstition in the Pigeon. Journal of Experimental Psychology, 38(2), 168-172. Retrieved May 26, 2019, from https://www.learning-theories.com

[74] Skinner, B. F., (1963). Operant behavior. American Psychologist, 18(8), 503. Retrieved May 26, 2019, from https://www.learningtheories.com

[75] Skinner, B. F., (1971). Operant conditioning. The Encyclopedia of Education, 7, 29-33. Retrieved May 26, 2019, from https://www.learning-theories.com

[76] Taras, H., \& Potts-Datema, W., (2005). Sleep and Student Performance at School. Retrieved May 26, 2019, from https://doi.org/10.1111/j.1746-1561.2005.00033.x

[77] Thorndike, E. L., (1905). The elements of psychology. New York: A. G. Seiler. Retrieved May 26, 2019, from https://www.officialgazette.gov.ph /programs/conditional-cashtransfer/

[78] Torre, B., (2016). Financing Education through the Pantawid Pamilyang Pilipino Program (4Ps). International Journal Humanities, Vol.6, No. 5. Retrieved May 26, 2019, from http://www.ijhssnet.com/journals /Vol_6_No_5_May_2016/13.pdf

[79] UNICEF, \& Regional Office for Central \& Eastern Europe, C. of I. S. \& B. S., (2007). Education for some more than others?: a regional study on education in Central and Eastern Europe and the Commonwealth of Independent States (CEE/CIS). Geneva: UNICEF Regional Office for CEE/CIS. Retrieved May 26, 2019, from https://www.learning-theories.com

[80] Velarde, R., \& Fernandez, L., (2011). Philippines Welfare and distributionalimpacts of the Pantawid Pamilyang Pilipino Program. Retrieved May 26, 2019, from ResearchGate website: https://www.researchgate.net/publication/254456352_Welfare_an d_distributionalimpacts_of_the_Pantawid_Pamilyang_Pilipino_Pr ogram

[81] Yemtsov, R., (2015). Philippines: CCT Proven to Keep Poor Children Healthy and in School. The State of Social Safety Nets 2015. The World Bank. Retrieved from www.worldbank.org

[82] Zimmerman, B. J., \& Schunk, D. H., (2007). Influencing Children's Self-Efficacy and Self-Regulation of Reading and Writing through Modeling. Retrieved from https://www.sciepub.com 